\title{
Studies of Gold Adsorption from Chloride Media
}

\author{
Mehmet Hakan Morcalia ${ }^{*}$, Bihter Zeytuncu ${ }^{b}$,Eda Ozlem ${ }^{c}$, Serdar Aktas ${ }^{c}$ \\ ${ }^{a}$ Faculty of Chemical and Metallurgical Engineering, Istanbul Technical University, \\ Maslak, 34469, Istanbul, Turkey \\ ${ }^{b}$ Applied Research Center of Materials Science and Production Technology, Istanbul Technical \\ University, Maslak, 34469, Istanbul, Turkey \\ 'Metallurgical \& Materials Division, Engineering Faculty, Marmara University, \\ Goztepe Campus, Istanbul, Turkey
}

Received: May 20, 2015; Revised: June 3, 2015

\begin{abstract}
In this paper, adsorption of gold from chloride media using commercial sorbent (Lewatit TP214 (L-214)) and biomass residue (rice hull (RH)) were investigated. The different adsorption parameters, sorbent dosage, contact time, temperature and $\mathrm{pH}$ of solution on adsorption (\%) were studied in detail on a batch sorption. Before the RH was activated, adsorption (\%) was poor compared with L-214. However, after the $\mathrm{RH}$ was activated at $1000{ }^{\circ} \mathrm{C}$ under an argon atmosphere, the gold adsorption (\%) increased four-fold. X-ray fluorescence (XRF) was used to explore the feasibility this material as an adsorbent for the removal of gold from aqueous solutions. The adsorption equilibrium data were best fitted with the Langmuir isotherm model. The maximum adsorption capacities, $\mathrm{Q}_{\max }$, at $25^{\circ} \mathrm{C}$ were found to be 93.46 and $108.70 \mathrm{mg} / \mathrm{g}$ for the activated rice hull (ARH) and L-214, respectively. Thermodynamic calculations using $\Delta \mathrm{H}^{\circ}, \Delta \mathrm{S}^{\circ}, \Delta \mathrm{G}^{\circ}$ and $\mathrm{E}_{\mathrm{a}}$ values indicate that the adsorption process was spontaneous and endothermic.
\end{abstract}

Keywords: adsorption, activated carbon, chloride solution, waste recovery

\section{Introduction}

Gold is a precious metal that is used in a wide variety of fields, such as in the electrical and electronic industries, in medicine, in jewellery and as a catalyst in various chemical processes $^{1}$. The diminishing availability of mineral resources and the increasing demand for gold metal emphasize the importance of its recovery from waste solutions and scrap materials ${ }^{2,3}$. During the past three decades, many recovery methods have been used, such as cementation ${ }^{4}$, precipitation ${ }^{5}$, ion-exchange ${ }^{6}$ and solvent extraction ${ }^{7-9}$, and adsorption ${ }^{10-13}$. Both precipitation and cementation techniques result in higher efficiencies, but they generally do not ensure a complete purification, i.e., further treatment is inevitably necessary. The ion-exchange method has the advantage of allowing the recovery of metallic ions with high efficiency, yet it is not cost-effective. Comparatively, adsorption appears the most suitable method for the recovery of gold from sources of low concentration due to its low cost and relatively high efficiency. Technical and economic concerns have led to a focus on lost-cost adsorbents.

$\mathrm{RH}$ is mainly composed of silica, and contains approximately $20 \%$ opaline silica in combination with a large amount of lignin. This intimate blend of silica and lignin give $\mathrm{RH}$ some remarkable properties such as capability of adsorbing precious metal ions from various solutions. Nowadays, they have been employed as building material and fuel ${ }^{13,14}$.

The L-214, a commercial resin, possesses a matrix of cross-linked polystyrene. The resin is one of the most

*e-mail: hakanmorcali@gmail.com commonly used sorbents that contain polystyrene-containing thiourea groups ${ }^{13}$.

The objective of the present work was to outline an effective adsorption performance from gold-bearing solution using RH and L-214 as sorbents. For this purpose, the following parameters were studied to investigate their effect on gold adsorption (\%): sorbent dosage, contact time, temperature, $\mathrm{pH}$ of solution, adsorption isotherms and adsorption thermodynamics. Following the gold adsorption process the obtained product was characterized using X-Ray Fluorescence (XRF).

\section{Material and Methods}

\subsection{Experimental procedures}

The L-214 was purchased from the Lanxess Company, Germany. The RH was obtained from the Gokbayrak Company, Turkey. The ARH $(\sim 250 \mu \mathrm{m})$ was used for all experiments.

$500 \mathrm{~g}$ of the dry RH was grounded using a mill (Siebtechnik TS 1000, Germany). Subsequently, the powder RH was washed several times with distilled water to eliminate water soluble impurities and then dried in an oven (Binder FD 115 , USA) at $105^{\circ} \mathrm{C} .300 \mathrm{~g}$ of this material was placed in a horizontal furnace in an inert atmosphere at $1000{ }^{\circ} \mathrm{C}$ for 3 hours. Then the ARH was taken from the furnace and cooled in a desiccator. Following cooling down to room temperature, the ARH was homogenized using a 3D-shaker (Turbula T2C, USA) for $60 \mathrm{~min}$. 
The potassium gold chloride powder $(99.9 \%$, Sigma Aldrich, Germany) was dissolved in the distilled-deionized water and then diluted with distilled-deionized water (TKA Smart2Pure, Germany). The concentrations of gold present in the solution were determined using ICP-OES (Perkin Elmer Inc., USA). The ICP-OES working conditions were given in Table 1.

This study was conducted in a batch system by varying one factor at a time (OFAT). For each experiment, $10 \mathrm{~mL}$ of gold solution was contacted with sorbents in a falcon tube. The shaking rate was adjusted to $100 \mathrm{rpm}$. The initial gold ion concentrations were set to $100 \mathrm{mg} / \mathrm{L}, 200 \mathrm{mg} / \mathrm{L}$, $300 \mathrm{mg} / \mathrm{L}, 400 \mathrm{mg} / \mathrm{L}, 500 \mathrm{mg} / \mathrm{L}$.

Effects of the following parameters were studied in detail on gold adsorption (\%): sorbent dosage, contact time, temperature, $\mathrm{pH}$ of solution. Besides, adsorption isotherms and adsorption thermodynamics were investigated. Thermo Niton XL3t-800 X-Ray Fluorescence (XRF, Thermo Scientific, USA) was employed for product characterization. It was used for the qualitative analysis of the samples before and after the adsorption experiment was carried out.

The adsorption percentage was calculated using the following Equation ${ }^{15}$ :

Adsorption, $\%=\frac{\mathrm{C}_{\mathrm{o}}-\mathrm{C}_{\mathrm{t}}}{\mathrm{C}_{\mathrm{o}}} * 100$

The adsorption capacity of the gold ion was calculated using the following general Equation ${ }^{15}$ :

$\mathrm{q}_{\mathrm{e}}=\frac{\mathrm{C}_{\mathrm{o}}-\mathrm{C}_{\mathrm{t}}}{\mathrm{m}} * \mathrm{~V}$

in which $\mathrm{q}_{e}$ is the amount of metal ions adsorbed at equilibrium per unit weight of sorbent $(\mathrm{mg} / \mathrm{g}), \mathrm{C}_{\mathrm{o}}$ and $\mathrm{C}_{\mathrm{t}}(\mathrm{mg} / \mathrm{L})$ are the gold ion concentrations present in the solution before and after adsorption, respectively, $\mathrm{V}$ is the volume of the solution (in L), and $\mathrm{m}$ is the amount of sorbent (in $\mathrm{g}$ ) used in the adsorption experiment.

\section{Results and Discussion}

\subsection{Effect of sorbent dosage on gold adsorption (\%)}

Figure 1 presents the gold adsorption percentage as a function of the sorbent dosages. It is apparent from Figure 1 that the gold sorption (\%) increased with increasing sorbent dosage because sorption reactions are thermodynamically favorable when the sorbent to metal ratio is high. This

Table 1. Instrumental parameters for the determination of gold by ICP-OES.

\begin{tabular}{cc}
\hline \multicolumn{2}{c}{ ICP-OES } \\
\hline Parameters & Value \\
\hline Instrument detector & Simultaneous \\
Cool gas flow & $13.0 \mathrm{~L} / \mathrm{min}$ \\
Plasma flow & $18 \mathrm{~L} / \mathrm{min}$ \\
Auxiliary flow & $0.7 \mathrm{~L} / \mathrm{min}$ \\
Nebulizer flow & $0.9 \mathrm{~L} / \mathrm{min}$ \\
RF power & $1400 \mathrm{~kW}$ \\
Nebulizer & Concentric $0.4 \mathrm{~L} / \mathrm{min}$ \\
Replicates & 3 \\
\hline
\end{tabular}

is consistent with our previous work ${ }^{13}$. As the amount of sorbent increases, more active sites for binding metal ions increase. A similar trend for the effect of adsorbent concentration was also observed in a study by Tasdelen et al. ${ }^{16}$ The L-214 (4 mg/mL) exhibited a 90\% of gold adsorption. With $8 \mathrm{mg} / \mathrm{mL}$ of the L-214, $99 \%$ of the gold was successfully adsorbed for $60 \mathrm{~min}$. For the same time period, $96 \%$ of the gold was adsorbed using $8 \mathrm{mg} / \mathrm{mL}$ of the $\mathrm{ARH}$.

\subsection{Effect of contact time on the gold adsorption capacity}

Figure 2 presents the effect of contact time on the adsorption percentage of gold by the ARH and L-214 in the range of 10 to $240 \mathrm{~min}$. The increased contact time has a positive effect on the gold adsorption (i.e., the adsorption (\%) increases with increased time) and reached equilibrium after after $120 \mathrm{~min}$ for the L-214 and after $180 \mathrm{~min}$ for the ARH. Initially, in the first $60 \mathrm{~min}$ the rate of adsorption was higher. Because all the adsorption sites on the sorbents were vacant and the concentration was high. Then, after approximately $180 \mathrm{~min}$ all the adsorption sites were filled with gold ions, resulting in unchanged adsorption percentages. This is an expected result because the adsorption rate of the ARH and L-214 were stable.

\subsection{Effect of temperature on gold adsorption (\%)}

In this experimental series, the effect of temperature on gold adsorption (\%) was studied in the range of $25^{\circ} \mathrm{C}$ to $45^{\circ} \mathrm{C}$. Figure 3 presents the percentage of gold adsorbed as a function of amount of sorbent over a range of temperatures.

As can be seen from Figure 3a, increasing the temperature has an important effect on gold adsorption for ARH. After $20 \mathrm{mg}$, an approximately $35 \%$ increment was obtained when the temperature increased from $25^{\circ} \mathrm{C}$ to $45^{\circ} \mathrm{C}$. Thus, temperature clearly has more of an effect for ARH than for $\mathrm{L}-214$. As is evident from Figure $3 \mathrm{~b}$ shows that temperature has little influence on the adsorption percentage for L-214. After $40 \mathrm{mg}$, only an approximately $10 \%$ increment was obtained when the temperature increased from $25^{\circ} \mathrm{C}$ to $45^{\circ} \mathrm{C}$. The gold adsorptions versus amount of sorbent curves at different temperatures are smooth and continuous, gradually leading to saturation, which indicates monolayer coverage of metal ions on the surface of the adsorbent ${ }^{3}$.

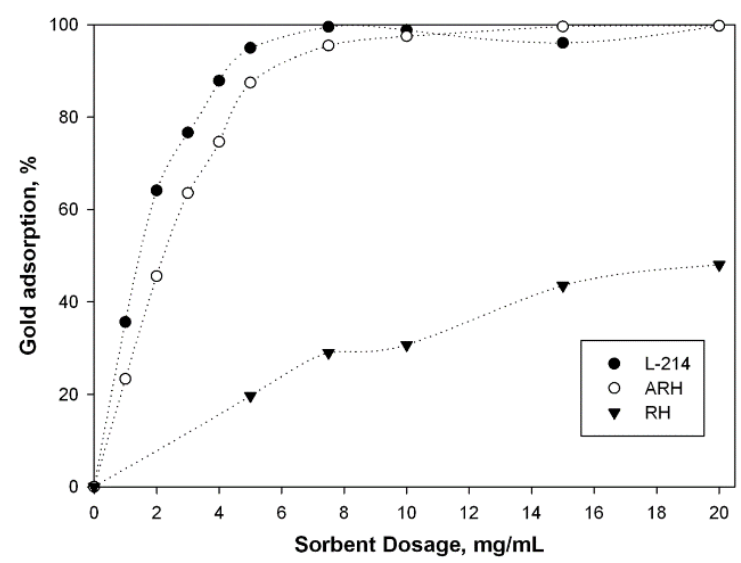

Figure 1. The effect of increasing sorbent dosage on gold adsorption (\%) $\left(60 \mathrm{~min}, 25^{\circ} \mathrm{C}, 100 \mathrm{rpm}, \mathrm{pH}=6.1 \text {, and } 10 \mathrm{~mL} \text { sol. }\right)^{13}$ 


\subsection{Effect of pH on gold adsorption (\%)}

The $\mathrm{pH}$ of a solution is one of the most important parameters for adsorption studies. So, the $\mathrm{pH}$ effect on gold sorption varying of 2 to 7 range was studied in detail. The obtained results which were the dependence of the gold adsorption (\%) on $\mathrm{pH}$ were presented in Figure 4. As seen from Figure 4, increasing the solution $\mathrm{pH}$ resulted in lower gold adsorption (\%) by the L-214 and ARH. It can be understood that gold adsorption should be carried out under acidic condition. This result was also observed in our previous work by Aktas \& Morcali ${ }^{13}$.

\subsection{Investigation of adsorption isotherms}

The adsorption isotherms of gold ions on these sorbents were studied at three different temperatures, specifically, $25^{\circ} \mathrm{C}, 35^{\circ} \mathrm{C}$, and $45^{\circ} \mathrm{C}$, by varying the initial concentrations of the solutions from 200 to $500 \mathrm{mg} / \mathrm{L}$ while keeping all other parameters constant.

The equilibrium data obtained were analyzed with respect to the Langmuir and Freundlich isotherms. The Freundlich adsorption isotherm and the Langmuir adsorption isotherm are frequently employed for identifying adsorption pattern. Using the empirical equation given by Freundlich, plots

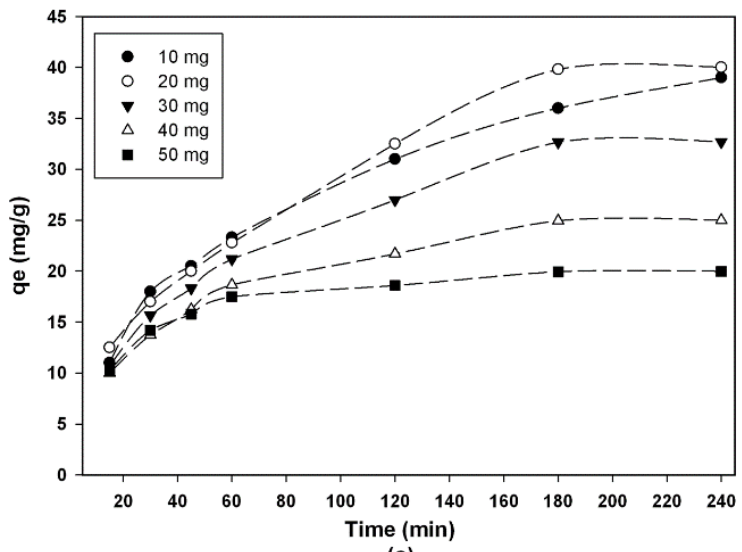

(a) regarding the final concentration of the ion to be adsorbed on the surface of the sorbent with regard to the amount of metal ions adsorbed per unit weight of sorbent are obtained. Thus, the Freundlich isotherm constant $(1 / \mathrm{n})$ is calculated. This model is valid for multilayer adsorption. However, in the Langmuir adsorption isotherm, plots regarding change in final ion concentration with regard to final ion concentration divided by the amount of metal ions adsorbed at equilibrium per unit weight of sorbent. The Langmuir isotherm model is valid for monolayer adsorption onto surface containing a finite number of identical sorption sites.

\subsubsection{Freundlich isotherms}

The data obtained for the adsorption of gold ions onto sorbents at an equilibrium concentration, $\mathrm{C}_{0}$, ranging from 200 to $500 \mathrm{mg} / \mathrm{L}$ were fitted to the Freundlich equation. The following linearized form of the Freundlich equation was used ${ }^{17,18}$ :

$\log \mathrm{q}_{\mathrm{e}}=\log \mathrm{K}_{\mathrm{f}}+1 / \mathrm{n} \log \mathrm{C}_{\mathrm{e}}$

in which, $q_{e}$ is the amount of metal ions adsorbed at equilibrium per unit weight of sorbent $(\mathrm{mg} / \mathrm{g}), \mathrm{C}_{\mathrm{e}}$ is the equilibrium ion concentration present in the solution after

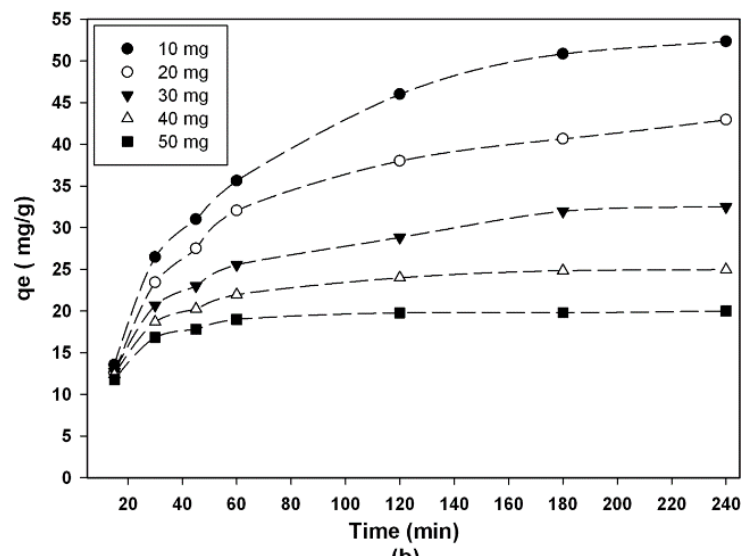

(b)

Figure 2. Gold adsorption capacity (mg/g) as a function of contact time by the (a) ARH and by (b) L-214 $\left(25^{\circ} \mathrm{C}, 100 \mathrm{rpm}, \mathrm{pH}=6.1\right.$, and $10 \mathrm{~mL}$ sol.).

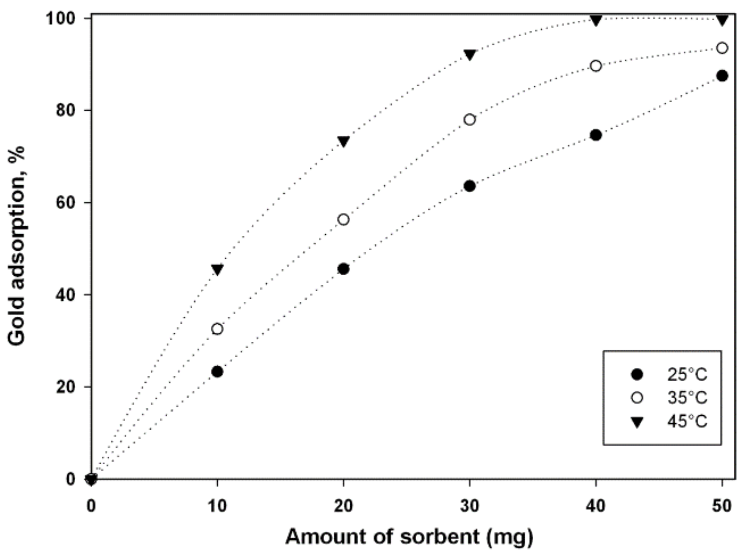

(a)

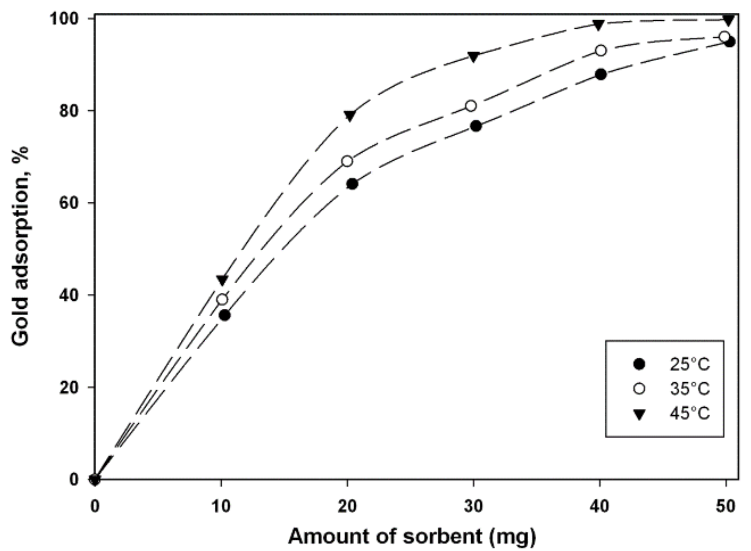

(b)

Figure 3. Gold adsorption (\%) as a function of amount of sorbent by (a) ARH; (b) L-214 (60 min., 100 ppm, 100 rpm, pH =6.1, and 10 $\mathrm{mL}$ sol.). 
adsorption, $\mathrm{K}_{\mathrm{f}}$ is the empirical Freundlich constant or the capacity factor (in $\mathrm{mg} / \mathrm{g}$ ), and $1 / \mathrm{n}$ is the Freundlich isotherm constant. The constants $\mathrm{K}_{\mathrm{f}}$ and $\mathrm{n}$ are empirical constants that are characteristic of the system and depend on nature of the sorbent, the nature of the sorbate, the temperature, and the pressure.

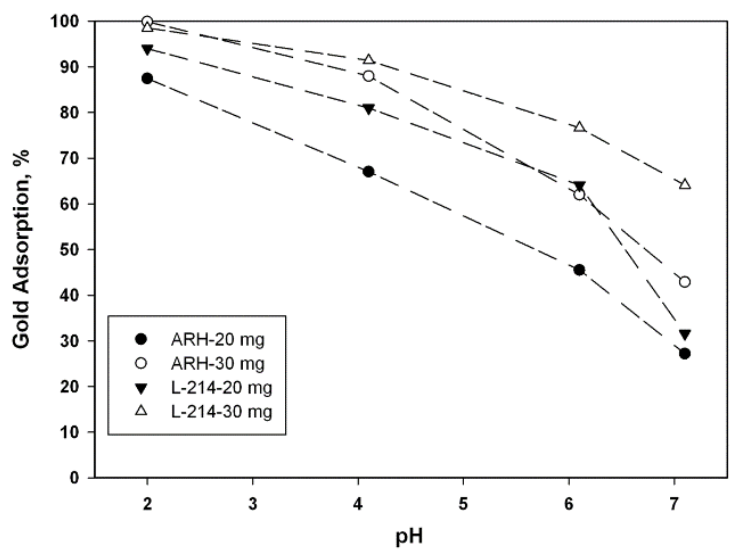

Figure 4. Gold adsorption (\%) as a function of solution $\mathrm{pH}$ by the ARH and L-214 $\left(25^{\circ} \mathrm{C}, 30 \mathrm{mg}, 60 \mathrm{~min}, 200 \mathrm{rpm}, 10 \mathrm{~mL} \text { sol. }\right)^{13}$

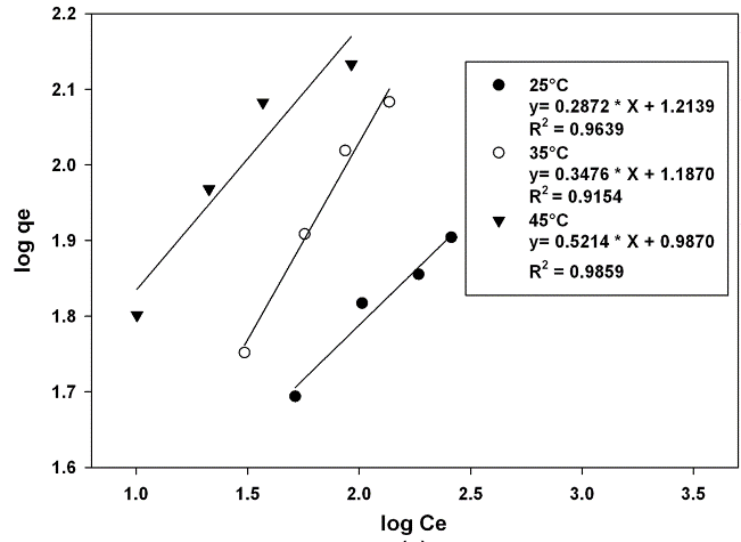

(a)
The plots of $\log \mathrm{q}_{\mathrm{e}}$ versus $\log \mathrm{C}_{\mathrm{e}}$ for gold ions adsorption onto the ARH and the L-214 yield straight lines with positive slopes, given by $1 / \mathrm{n}$, and intercepts at $\log \mathrm{K}_{\mathrm{f}}$, as shown in Figure 5.

\subsubsection{Langmuir isotherms}

The following linearized form of the Langmuir equation was used to analyze the adsorption data for the adsorption of gold on the ARH and the L-214, respectively. The Langmuir equation is provided below ${ }^{19,20}$ :

$\mathrm{C}_{\mathrm{e}} / \mathrm{q}_{\mathrm{e}}=\frac{1}{\left(\mathrm{Q}_{\max } * \mathrm{~K}_{\mathrm{L}}\right)}+\frac{1}{\mathrm{Q}_{\max }} * \mathrm{C}_{\mathrm{e}}$

where $\mathrm{q}_{\mathrm{e}}$ is the amount of metal ions adsorbed at equilibrium per unit weight of sorbent $(\mathrm{mg} / \mathrm{g}), \mathrm{C}_{\mathrm{e}}$ is the equilibrium concentration of the sorbate in solution following adsorption, $\mathrm{Q}_{\max }$ is the maximum adsorption capacity $(\mathrm{mg} / \mathrm{g})$ (which is generally called the monolayer capacity), and $\mathrm{K}_{\mathrm{L}}$ is the Langmuir equilibrium constant $(\mathrm{L} / \mathrm{mg})$. Figure 6 shows the Langmuir adsorption isotherm plot of $\mathrm{C}_{\mathrm{e}} / \mathrm{q}_{\mathrm{e}}$ versus $\mathrm{C}_{\mathrm{e}}$.

The adsorption isotherms of both a ARH and L-214 under different conditions were calculated and given in Table 2 .

The values of each model and the correlation coefficient, $\mathrm{R}^{2}$, were calculated from these plots. The linearity of

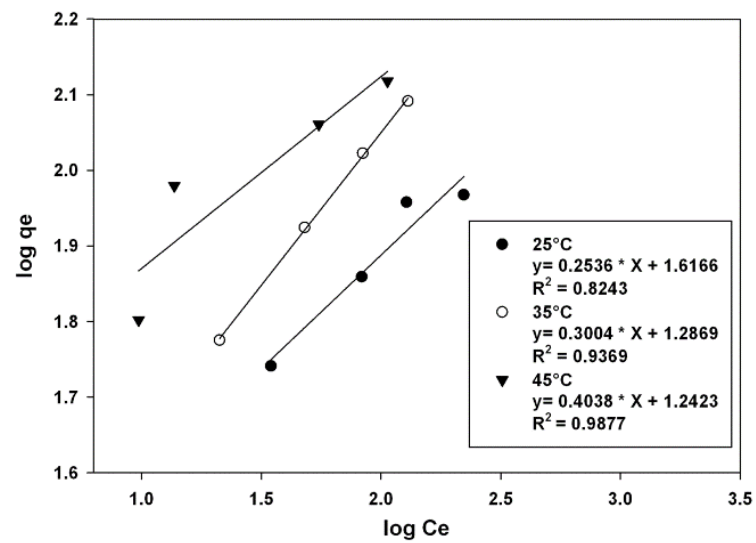

(b)

Figure 5. The Freundlich isotherm of gold onto (a) ARH and (b) L-214 (30 mg sorbent, 60 min, $100 \mathrm{rpm}, \mathrm{pH}=6.1,10 \mathrm{~mL}$ sol. at a concentration of $200-500 \mathrm{mg} / \mathrm{L}$ ).

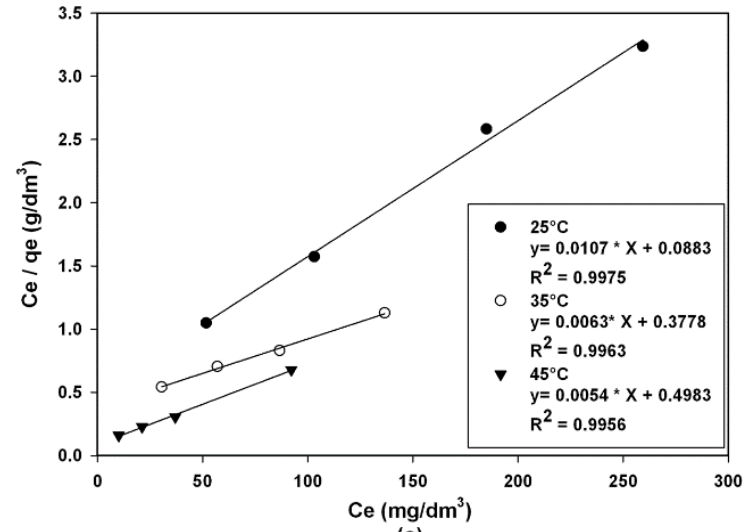

(a)

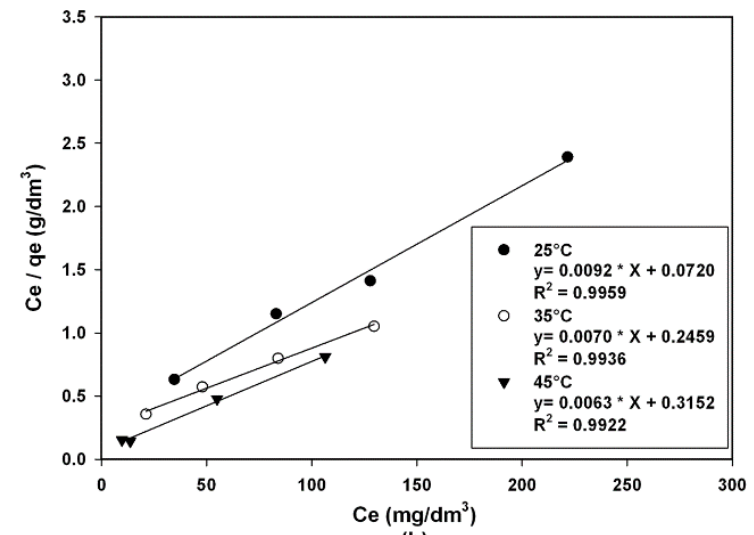

(b)

Figure 6. Freundlich isotherm of gold adsorbed onto (a) ARH and (b) L-214 (30 mg sorbent, $60 \mathrm{~min}, 100 \mathrm{rpm}, \mathrm{pH}=6.1,10 \mathrm{~mL}$ sol. at a concentration of 200-500 ppm). 
these plots indicates the applicability of the two models. The correlation coefficients, $R^{2}$, showed that the Langmuir isotherm $\left(R^{2} \geq 0.99\right)$ fits better than the Freundlich isotherm $\left(R^{2}<0.99\right)$. This result indicates that the adsorption process of gold ion onto the surfaces of L-214 and ARH is a monolayer adsorption process.

The comparison of the adsorption capacity of the ARH and L-214 with some previously used adsorbents is provided in Table 3.

The results show that the ARH and L-214 are very effective for the removal of gold ions from aqueous solutions, and the maximum monolayer adsorption capacities, $\mathrm{Q}_{\max }$, of gold ions obtained by the ARH and L-214 were comparable with the literature data.

\subsection{Investigation of adsorption thermodynamics}

The temperature range chosen in this study was $298 \mathrm{~K}$ to $318 \mathrm{~K}$. The adsorption percentage increases with increasing temperature. Thermodynamic parameters for this adsorption process, such as enthalpy change $\left(\Delta \mathrm{H}^{\circ}\right)$, entropy change $\left(\Delta \mathrm{S}^{\circ}\right)$, and the free energy of specific adsorption $\left(\Delta \mathrm{G}^{\circ}\right)$, was calculated using the following equations ${ }^{24}$ :

$\mathrm{K}_{\mathrm{c}}=\frac{\mathrm{C}_{\mathrm{AC}}}{\mathrm{C}_{\mathrm{e}}}$

where $\mathrm{K}_{\mathrm{c}}$ is the equilibrium constant, $\mathrm{C}_{\mathrm{AC}}$ and $\mathrm{C}_{\mathrm{e}}$ are the equilibrium concentrations (in $\mathrm{mg} / \mathrm{L}$ ) of the gold ion adsorbed and left in the solution, respectively. $\Delta \mathrm{G}^{\circ}$ was calculated from the following relationship:

$\Delta \mathrm{G}=\Delta \mathrm{G}^{\circ}+\mathrm{RT} \ln \mathrm{K}_{\mathrm{c}}$

At equilibrium, $\Delta \mathrm{G}=0$, thus

$\Delta \mathrm{G}^{\circ}=-\mathrm{RT} \ln \mathrm{K}_{\mathrm{c}}$ where, $\mathrm{T}$ is absolute temperature in Kelvin, and $\mathrm{R}$ is the gas constant.

$\Delta \mathrm{G}^{\circ}$ was calculated from the following equations:

$\Delta \mathrm{G}^{\circ}=\Delta \mathrm{H}^{\circ}-\mathrm{T} \Delta \mathrm{S}^{\circ}$

The following formula is known as Van't Hoff equation.

$\frac{\partial\left(\ln _{\mathrm{c}}\right)}{\partial(1 / \mathrm{T})}=\frac{-\Delta \mathrm{H}}{\mathrm{R}}$

The enthalpy change $\left(\Delta \mathrm{H}^{\circ}\right)$, and the entropy change $\left(\Delta \mathrm{S}^{\circ}\right)$ were calculated from the slope and from the intercept in linear plots of $\ln \mathrm{K}_{\mathrm{c}}$ versus $1000 / \mathrm{T}$ using the equation presented below, as shown in Figure 7.

$\ln \mathrm{K}_{\mathrm{c}}=\frac{\Delta \mathrm{S}^{\circ}}{\mathrm{R}}-\frac{\Delta \mathrm{H}^{\circ}}{\mathrm{RT}}$

The free energy of adsorption $\left(\Delta \mathrm{G}^{\circ}\right)$ could also be calculated using the Equation 7.

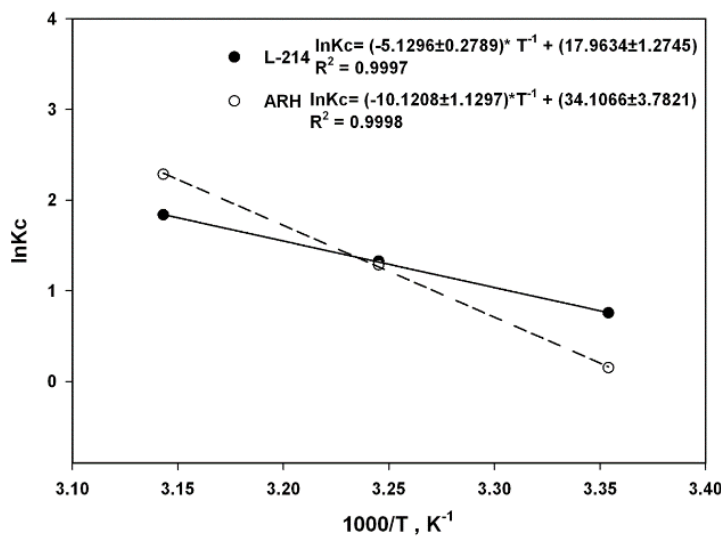

Figure 7. $\operatorname{lnK}$ versus $1000 / \mathrm{T}$ for gold on L-214 and ARH (30 mg sorbent, $60 \mathrm{~min}, 100 \mathrm{rpm}, \mathrm{pH}=6.1, \mathrm{C}_{\mathrm{o}}=400 \mathrm{ppm}$, and $10 \mathrm{~mL}$ sol.).

Table 2. Freundlich and Langmuir constants for the adsorption of gold ions at various temperatures.

\begin{tabular}{|c|c|c|c|c|c|c|}
\hline \multicolumn{4}{|c|}{ ARH } & \multicolumn{3}{|c|}{ L-214 } \\
\hline \multicolumn{7}{|c|}{ Freundlich isotherm constants } \\
\hline Temp. $\left({ }^{\circ} \mathrm{C}\right)$ & $\begin{array}{c}\mathrm{K}_{\mathrm{f}}(\mathrm{mg} / \mathrm{g})^{*} \\
(\mathrm{~L} / \mathrm{mg})^{1 / \mathrm{n}}\end{array}$ & $\mathbf{n}$ & $\mathbf{R}^{2}$ & $\begin{array}{c}K_{\mathrm{f}}(\mathrm{mg} / \mathrm{g})^{*} \\
(\mathrm{~L} / \mathrm{mg})^{1 / \mathrm{n}}\end{array}$ & $\mathbf{n}$ & $\mathbf{R}^{2}$ \\
\hline 25 & 16.36 & 3.48 & 0.96 & 41.36 & 3.94 & 0.82 \\
\hline 35 & 15.38 & 2.88 & 0.92 & 19.36 & 3.33 & 0.94 \\
\hline 45 & 9.71 & 1.92 & 0.99 & 17.47 & 2.48 & 0.99 \\
\hline \multicolumn{7}{|c|}{ Langmuir isotherm constants } \\
\hline Temp. $\left({ }^{\circ} \mathrm{C}\right)$ & $K_{L}(\mathbf{L} / \mathbf{m g})$ & $Q_{\max }(\mathrm{mg} / \mathrm{g})$ & $\mathbf{R}^{2}$ & $K_{L}(\mathbf{L} / \mathbf{m g})$ & $Q_{\max }(\mathrm{mg} / \mathrm{g})$ & $\mathbf{R}^{2}$ \\
\hline 25 & 0.12 & 93.46 & 0.99 & 0.13 & 108.70 & 0.99 \\
\hline 35 & 0.02 & 158.73 & 0.99 & 0.03 & 142.86 & 0.99 \\
\hline 45 & 0.01 & 185.19 & 0.99 & 0.02 & 158.73 & 0.99 \\
\hline
\end{tabular}

Table 3. Maximum adsorption capacities for the adsorption of gold ions, onto various adsorbents reported in the literature.

\begin{tabular}{lcc}
\hline \multicolumn{1}{c}{ Adsorbents } & $\mathbf{Q}_{\max }(\mathbf{m g} / \mathbf{g})$ & Reference \\
\hline PVA-immobilized fungal biomass & 94.34 & {$[21]$} \\
Cross linked chitosan resin chemically modified with 1-lysin & 70.34 & {$[22]$} \\
Rice hull carbon & 149.69 & {$[23]$} \\
L-214 & 108.70 & This study \\
ARH & 93.46 & This study \\
\hline
\end{tabular}


The values of the thermodynamic parameters, $\Delta \mathrm{H}^{\circ}, \Delta \mathrm{S}^{\circ}$, $\Delta \mathrm{G}^{\circ}$, and $\mathrm{E}_{\mathrm{a}}$ for the gold adsorption onto L-214 and the $\mathrm{ARH}$ was calculated using Equations 5-10 and are given in Table 4.

As shown in Figure 3, an increase in the value of the adsorption percentage with increasing temperature indicates the endothermic character of gold adsorption onto the sorbents. The value of $\Delta \mathrm{H}^{\circ}{ }_{298 \mathrm{~K}}$ for the gold adsorption onto the $\mathrm{ARH}$ and L-214 are calculated to be 84.14 and $42.65 \mathrm{~kJ} / \mathrm{mol}$, respectively. In order to calculate the activation energy, the following formula has been employed ${ }^{24}$ :

$\Delta \mathrm{H}^{\circ}=E_{a}-R T$

Activation energies were presented in Table 4. The negative values of the free energy of specific adsorption $\left(\Delta \mathrm{G}^{\circ}\right)$ for the adsorption of gold onto the sorbents, as shown in Table 4, indicate that the process is spontaneous ${ }^{3}$. The value of $\Delta \mathrm{G}^{\circ}$ becomes more negative as the temperature increases, indicating an increasing driving force toward equilibrium, thereby resulting in a greater adsorption percentage at higher temperatures. The increase in the adsorption capacity of gold onto the sorbents at higher temperature may be attributed to an enlargement of the pore size or to increased activation of the adsorbent surface. The greater extent of gold adsorption at higher temperatures becomes apparent in an increase in the monolayer capacity. The process can only occur spontaneously if the entropy of the system increases and the value of $T^{*} \Delta \mathrm{S}^{\circ}$ becomes greater than the value of $\Delta \mathrm{H}^{\circ}$, yielding a negative value for the free energy of specific adsorption, $\Delta \mathrm{G}^{\circ}$. The adsorption of gold onto the sorbents is accompanied by an increase in the entropy of the overall system. The positive value of $\Delta \mathrm{S}^{\circ}$ indicates an increase in the randomness at the solid/solution interface during the adsorption of the metal ion onto the ARH and L-214. The results are in good agreement with those of other base metal ions adsorbed onto $\mathrm{ARH}^{24}$ and $\mathrm{L}-214^{25}$.

\subsection{Experiments for technogenic waste solution}

In order to evaluate adsorption efficacy of both adsorbents, gold containing e-scraps such motherboard and central process unit (CPU's) mixture has been used. First, the mixture was crushed, ground and subjected to leaching process in a 3:1 (by volume) mixture of $\mathrm{HCl}$ and $\mathrm{HNO}_{3}$ solutions, i.e., aqua regia ${ }^{26}$. The chemical composition of the e-scrap is displayed in Table 5.
After the dissolution was complete, the obtained solution was vaporized to render it free from $\mathrm{NO}_{2}$. After the residue was removed by filtration, the remaining solution was diluted to $0.5 \mathrm{~L}$. The new solution, which exhibited a $\mathrm{pH}$ value of 0.51 , contained $103.5 \mathrm{ppm} \mathrm{Au}^{3+}$. The adsorption percentage and adsorption capacity are displayed in the Figure 8 and Figure 9, respectively.

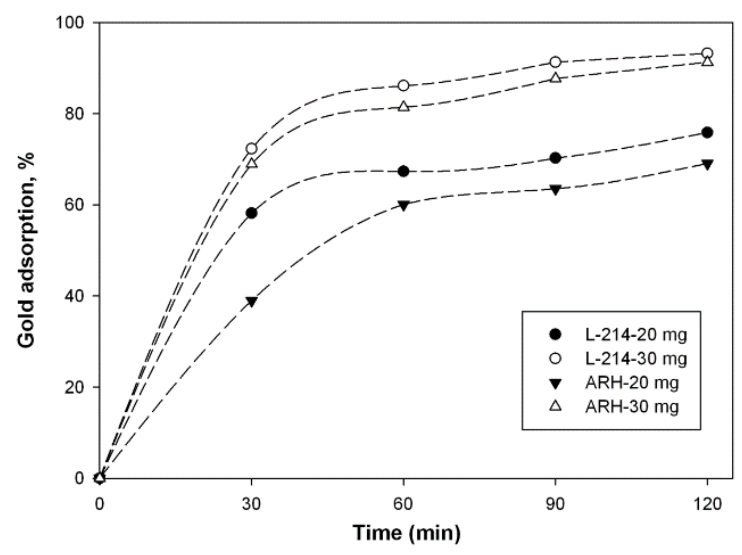

Figure 8. Gold adsorption (\%) as a function of time by the ARH and $\mathrm{L}-214\left(25^{\circ} \mathrm{C}, 100 \mathrm{rpm}, \mathrm{pH}=0.51,10 \mathrm{~mL}\right.$ waste sol. $)$.

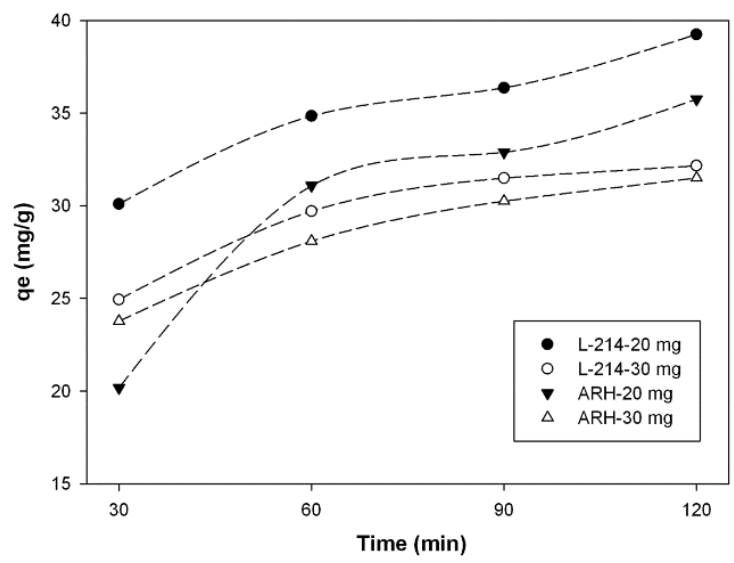

Figure 9. Gold adsorption capacity $(\mathrm{mg} / \mathrm{g}$ ) as a function of contact time by the ARH and $\mathrm{L}-214\left(25^{\circ} \mathrm{C}, 100 \mathrm{rpm}, \mathrm{pH}=0.51\right.$, and 10 $\mathrm{mL}$ waste sol.).

Table 4. Thermodynamic constants for the adsorption of gold ions at various temperatures.

\begin{tabular}{ccccccccc}
\hline & \multicolumn{1}{c}{ ARH } & \multicolumn{3}{c}{$\mathbf{L - 2 1 4}$} \\
\hline Temp. (K) & $\begin{array}{c}\Delta \mathbf{G}^{\circ} \\
(\mathbf{k J} / \mathbf{m o l})\end{array}$ & $\begin{array}{c}\Delta \mathbf{H}^{\circ} \\
(\mathbf{k J} / \mathbf{m o l})\end{array}$ & $\begin{array}{c}\Delta \mathbf{S}^{\circ} \\
(\mathbf{J} / \mathbf{m o l} \mathbf{K})\end{array}$ & $\begin{array}{c}\mathbf{E}_{\mathrm{a}} \\
(\mathbf{k J} / \mathbf{m o l})\end{array}$ & $\begin{array}{c}\Delta \mathbf{G}^{\circ} \\
(\mathbf{k J} / \mathbf{m o l})\end{array}$ & $\begin{array}{c}\Delta \mathbf{H}^{\circ} \\
(\mathbf{k J} / \mathbf{m o l})\end{array}$ & $\begin{array}{c}\Delta \mathbf{S}^{\circ} \\
(\mathbf{J} / \mathbf{m o l} \mathbf{~ K})\end{array}$ & $\begin{array}{c}\mathbf{E}_{\mathbf{a}} \\
(\mathbf{k J} / \mathbf{m o l})\end{array}$ \\
\hline 298 & -0.37 & 84.14 & 0.28 & 87 & -1.87 & 42.65 & 0.15 & 45 \\
308 & -3.29 & & & & -3.39 & & & \\
318 & -6.04 & & & & -4.86 & & \\
\hline
\end{tabular}

Table 5. Compositions of electronic waste mixture.

\begin{tabular}{ccccccccccc}
\hline \multicolumn{10}{c}{ Wt.\% } \\
\hline $\mathbf{C u}$ & $\mathbf{Z n}$ & $\mathbf{N i}$ & $\mathbf{F e}$ & $\mathbf{S n}$ & $\mathbf{V}$ & $\mathbf{C r}$ & $\mathbf{M n}$ & $\mathbf{A u}$ & Pd & Remaning \\
\hline 36.06 & 4.41 & 6.61 & 5.65 & 9.07 & N/A* & N/A* & N/A* & 0.13 & N/A* & 38.07 \\
\hline *Not available. & & & & &
\end{tabular}


As can be seen from the figure that both sorbents are efficient for the removal of gold ions from the waste solution.

\subsection{Product characterization}

The Thermo Niton software package was used for the qualitative analysis of the samples (Thermo Scientific Instruments). This package implements the fundamental parameter method for the computation of concentrations for various trace constituents in the samples. Representative spectra of the samples are given in Figure 10.

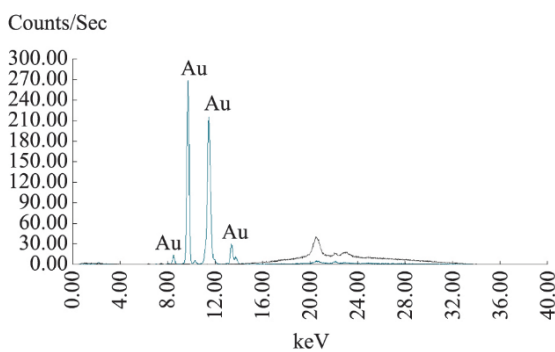

(a)

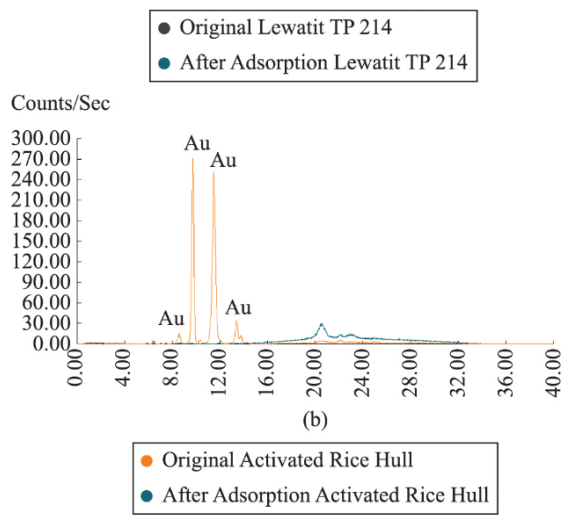

Figure 10. XRF spectra of the (a) L-214 and (b) ARH.

\section{References}

1. Das N. Recovery of precious metals through biosorption: a review. Hydrometallurgy. 2010; 103(1-4):180-189. http:// dx.doi.org/10.1016/j.hydromet.2010.03.016.

2. Brooks CS. Metal recovery from industrial wastes. Chelsea: Lewis Publishers; 1991.

3. Hussain G and Khan MA. Adsorption of gold (III) from aqueous solutions on bagasse ash. Journal of the Chemical Society of Pakistan. 2011; 33:317-323.

4. Lee HY, Kim SG and Oh JK. Cementation behavior of gold and silver onto $\mathrm{Zn}, \mathrm{Al}$ and $\mathrm{Fe}$ powders from acid thiourea solutions. Canadian Metallurgical Quarterly. 1997; 36:149-155.

5. Haque KE. Recovery of dissolved gold by sodium borohydride NaBH4 reduction. US Patent 5,178,665. 1993 January 12.

6. Alguacil FJ, Adeva P and Alonso M. Processing of residual gold (III) solutions via ion exchange. Gold Bulletin. 2005; 38(1):9-13. http://dx.doi.org/10.1007/BF03215222.

7. Salvadó V, Hidalgo M, Masana A, Mufioz M, Valiente M and Muhammed M. Extraction of gold (III) from hydrochloric acid solutions by tri-isobutyl phosphine sulfide in toluene. Solvent
The continuous line spectrum is for the original sample, which was not allowed to adsorb any metals. The other spectrum is for the sample which adsorbed gold. Finally, the high spectrum corresponds to the sample which adsorbed gold.

\section{Conclusion}

This study demonstrated that both the commercially available L-214 and ARH, a biomass residue, can be effective for the adsorption of gold ions from aqueous solutions. The proposed process has been demonstrated to treat electronic waste solution. Thus, removal of gold has been successfully achieved using these two sorbents.

Temperature has shown to be an important effect on gold adsorption for both sorbents but its influence was more profound for ARH. An approximately 35\% increment was obtained using $20 \mathrm{mg}$ ARH when the temperature increased from $25^{\circ} \mathrm{C}$ to $45^{\circ} \mathrm{C}$.

Equilibrium adsorption data were well fitted by the Langmuir model. The adsorption maximum capacities, $\mathrm{Q}_{\max }$, at $25^{\circ} \mathrm{C}$ of gold ions onto ARH and L-214 were found to be 93.46 and $108.70 \mathrm{mg} / \mathrm{g}$, respectively. The enthalpy change $\left(\Delta \mathrm{H}^{\circ}{ }_{298 \mathrm{~K}}\right)$ and the entropy change $\left(\Delta \mathrm{S}^{\circ}{ }_{298 \mathrm{~K}}\right)$ for this adsorption process for the ARH were calculated to be $84.14 \mathrm{~kJ} / \mathrm{mol}$ and $0.284 \mathrm{~kJ} / \mathrm{mol} \mathrm{K}$, respectively, and the same quantities were calculated for L-214 to be $42.65 \mathrm{~kJ} / \mathrm{mol}$ and $0.149 \mathrm{~kJ} / \mathrm{mol}$ $\mathrm{K}$, respectively. Thus, the adsorption process was found to be endothermic. The RH, abundantly available in Turkey, was demonstrated to have promising adsorption capacity comparable to L-214. For the future studies, ARH should be tested for adsorption of other precious metals and compared with commercial products such activated carbon.

\section{Acknowledgements}

The authors thank Marmara University for supporting the BAPKO project No: FEN-E-080415-0110.

Extraction Ion Exchange. 1990; 8(3):491-502. http://dx.doi. org/10.1080/07366299008918013.

8. Martínez S, Sastre A and Alguacil FJ. Gold extraction equilibrium in the system Cyanex 921-HCl-Au (III). Hydrometallurgy. 1997; 46(1-2):205-214. http://dx.doi.org/10.1016/S0304386X(97)00014-5.

9. Barroso MA, López FA, Sastre A and Alguacil FJ. Study of the extraction of gold(III) in aqueous hydrochloric acid media by the phosphine oxide Cyanex 925. Hydrometallurgy. 1997; 45(12):199-209. http://dx.doi.org/10.1016/S0304-386X(96)00080-1.

10. Nakbanpote W, Thiravetyan P and Kalambaheti C. Preconcentration of gold by rice husk ash. Minerals Engineering. 2000; 13(4):391400. http://dx.doi.org/10.1016/S0892-6875(00)00021-2.

11. Hughes HC and Linge HG. The Kinetics of Gold Loading from Gold (III) Chloride Solution onto Fresh Activated Coconut Carbon. Hydrometallurgy. 1989; 22(1-2):57-65. http://dx.doi. org/10.1016/0304-386X(89)90041-8.

12. Fritz JS and Millen WG. Gold recovery from aqueous solutions. US Patent 3,736,126. 1973 May 29.

13. Aktas S and Morcali MH. Gold uptake from dilute chloride solutions by a Lewatit TP 214 and activated rice husk. International 
Journal of Mineral Processing. 2011; 101(1-4):63-70. http:// dx.doi.org/10.1016/j.minpro.2011.07.007.

14. Tóth J. Adsorption: theory, modeling and analysis. New York: Marcel Dekker; 2001.

15. Ruthven DM. Principles of adsorption and adsorption processes. New York: Wiley-Interscience Publication; 1984.

16. Tasdelen C, Aktas S, Acma E and Guvenilir Y. Gold recovery from dilute gold solutions using DEAE-cellulose. Hydrometallurgy. 2009; 96(3):253-257. http://dx.doi.org/10.1016/j. hydromet.2008.10.006.

17. Freundlich H. Uber die adsorption in losungen. Zeitschrift für Physikalische Chemie. 1906; 57:387-470.

18. Liu SY, Gao J, Yang YJ, Yang YC and Ye ZX. Adsorption intrinsic kinetics and isotherms of lead ions on steel slag. Journal of Hazardous Materials. 2010; 173(1-3):558-562. http://dx.doi. org/10.1016/j.jhazmat.2009.08.122. PMid:19766391.

19. Langmuir I. The adsorption of gases on plane surfaces of glass, mica and platinum. Journal of the American Chemical Society. 1918; 40(9):1361-1403. http://dx.doi.org/10.1021/ja02242a004.

20. Jaman H, Chakraborty D and Saha P. A study of the thermodynamics and kinetics of copper adsorption using chemically modified rice husk. Clean: Soil, Air, Water. 2009; 37:704-711.

21. Khoo K and Ting Y. Biosorption of gold by immobilized fungal biomass. Biotechnology and Bioengineering. 2001;
8(1):51-59. http://dx.doi.org/10.1016/S1369-703X(00)00134-0. PMid:11356371.

22. Fujiwara K, Ramesh A, Maki T, Hasegawa H and Ueda K. Adsorption of platinum (IV), palladium (II) and gold (III) from aqueous solutions onto L-lysine modified crosslinked chitosan resin. Journal of Hazardous Materials. 2007; 146(1-2):39-50. http://dx.doi.org/10.1016/j.jhazmat.2006.11.049. PMid:17184914.

23. Chand R, Watari T, Inoue K, Kawakita H, Luitel HN, Parajuli $\mathrm{D}$, et al. Selective adsorption of precious metals from hydrochloric acid solutions using porous carbon prepared from barley straw and rice husk. Minerals Engineering. 2009; 22(15):1277-1282. http://dx.doi.org/10.1016/j.mineng.2009.07.007.

24. Kula I, Uğurlu M, Karaoğlu H and Celik A. Adsorption of $\mathrm{Cd}(\mathrm{II})$ ions from aqueous solutions using activated carbon prepared from olive stone by $\mathrm{ZnCl} 2$ activation. Bioresource Technology. 2008; 99(3):492-501. http://dx.doi.org/10.1016/j. biortech.2007.01.015. PMid:17350829.

25. Won SW, Park J, Mao J and Yun YS. Utilization of PEI-modified Corynebacterium glutamicum biomass for the recovery of $\mathrm{Pd}(\mathrm{II})$ in hydrochloric solution. Bioresource Technology. 2011; 102(4):3888-3893. http://dx.doi.org/10.1016/j.biortech.2010.11.106. PMid:21185173.

26. Naeem S, Zafar U, Altaf A and Inayat A. Adsorption studies of Cr (IV) on Rice Husk Ash (Rha). Journal of the Chemical Society of Pakistan. 2009; 31:379-382. 